activity of any of the three enzymes during the first 4 days of life. By the eighth day, however, UDPXT and UDPGST activities increased 80 and $88 \%$ as compared with controls, respectively. UDPGT demonstrated no enhancement on day 8 in response to phenobarbital. By the 12th day, enhancement of UDPGT became significant, reaching maximal increase on day 16 .

\section{REFERENCES AND NOTES}

1. Bakken, A. F.: Effects of unconjugated bilirubin on bilirubin-UDP-glucuronyl transferase activity in liver of newborn rats. Pediat. Res.. 3: 205 (1969).

2. Brown, A. K., and Zuelzer, W. W.: Studies on the neonatal development of the glucuronide conjugating system. J. Clin. Invest., 37: 332 (1957).

3. Catz, C.. and Yaffe, S. J.: Barbiturate enhancement of bilirubin conjugation and excretion in young and adult animals. Pediat. Res., 2: 361 (1968).

4. Cornelius, C. E.. Kelley, K. C., and Himes, J. A.: Heterogeneity of bilirubin conjugates in several species. Cornell Vet., 65: 90 (1975).

5. Fevery, J., Leroy, P., Van De Vijver, M., and Heirwegh, K. P. M.: Structures of bilirubin conjugates synthesized in vitro from bilirubin and uridine diphosphate glucuronic acid, uridine diphosphate glucose or uridine diphosphate xylose by preparation from rat liver. Biochem. J.. 129: 635 (1972).

6. Gartner, L. M., and Arias, I. M.: Hormonal control of hepatic bilirubin transpor and conjugation. Amer. J. Physiol., 222: 1091 (1972).

7. Gartner, L. M., and Lane, D. L.: The physiology of physiologic hyperbilirubinemia of the newborn. Medical Primatology 1972. Proceedings of the Third Conference on Experimental Medicine and Surgery in Primates, Lyon, 1972, Part I. p. 237 (Karger, Basel, 1972).

8. Gartner, L. M. Lee, K. S., Vaisman, S. L.ane, D., and Zarafu, I.: The effect of prenatal and neonatal phenobarbital administration on hepatic bilirubin uptake, conjugation, and excretion in the newborn Macaca mulatta (rhesus) monkey. J. Pediat. (In press.)

9. Graham, A. B., Woodcock, B. G., and Wood, G. C.: The phospholipid-dependence of uridine diphosphate glucuronyl transferase. Biochem. J., 137: 567 (1974).

10. Halac, E., and Sicignano, C.: Re-evaluation of the influence of sex, age, pregnancy and phenobarbital on the activity of UDP-glucuronyl transferase in rat liver. J. Lab. Clin. Med., 73: 677 (1969).
11. Heirwegh, K. P. M., Van Hees, G. P., Leroy, P., Van Roy, F. P., and Jansen, F. $H$.: Heterogeneity of bile pigments conjugates as revealed by chromatography of their ethyl anthranilate azopigments. Biochem. J., 120: 877 (1970).

12. Jansen, P. L. M., and Arias, I. M.: Delipidation and reactivation of UDP glucuronosyl transferase from rat liver. Biochim. Biophys. Acta, 391: 28 (1975).

13. Krasner, J., Juchau, M. R., and Yaffe, S. J.: Postnatal development changes in hepatic bilirubin UDP-glucuronyl transferase. Biol. Neonate, 23: 381 (1973).

14. Lowry, O. H., Rosebrough, N. J., Farr, A. L., and Randall, R. J.: Protein measurement with the Folin phenol reagent J. Biol. Chem., 193: 265 (195I).

15. Runyon, R. P., and Haber. A.: Fundamentals of Behavioral Statistics (AddisonWesley Publishing Co., Reading, Mass.

16. Trolle, D.: Decrease of total serum bilirubin concentration in newborn infants after phenobarbitone treatment. Lancet, ii: 705 (1968).

17. Vaisman, S.: Tesis Universidad de Chile. Hiperbilirrubinemia neonatal y drogas. (Santiago, Chile, January 1972).

18. Vaisman, S. Galecio, R. Erazo, R. and Kunzack, H.: Hiperbilirrubinemia del recien nacido y fenobarbital I. Recien nacido de termino. Rev. Chil. Pediat., 4 245 (1971).

19. Vaisman S. L., Lee, K. S and Gartner L. M. Diminished enhancement of hepatic UDP-glucuronyl transferase (bilirubin) by phenobarbital during pregnancy in the rat. Biol. Neonat. 28: 287 (1976).

20. Wong, K. P.: Bilirubin glucosyl and glucuronyl transferases: A comparative study and the effects of drugs. Biochem. Pharmacol., 2l: 1485 (1972).

21. Zakim, D., Goldenberg, J., and Vessey, D. A.: Influence of membrane lipids on the regulatory properties of UDP-glucuronyl transferase. Europ. J. Biochem. 38: $59(1973)$.

22. This work was supported by grants from National Institute of Child Health and Disease (no. 5R01-HD03783). National Institutes of Health International Fellowship Award (no. 3F05 TW1850-0140151), the Gail I. Zuckerman Foundation for Research in Chronic Liver Diseases of Children, and the Liver Research Center of the Albert Einstein College of Medicine.

23. Dr. S. Vaisman was a recipient of a National Institutes of Health International Fellowship.

24. Dr. L. Gartner is a Career Development Awardee from National Institute of Child Health and Disease.

25. Requests for reprints should be addressed to: L. M. Gartner, M.D., Department of Pediatrics, Albert Einstein College of Medicine, 1300 Morris Park Ave., Bronx, N. Y. 10461 (USA).

26. Accepted for publication June 4, 1976.
Angiotensin II

Bartter's syndrome

plasma renin activity renin-aldosterone axis sodium urinary excretion

\title{
Effect of Sodium Restriction and Angiotensin II Infusion in Bartter's Syndrome
}

\author{
L. SANN, ${ }^{(30)}$ M. DAVID, P. RICHARD, D. FLORET, J. SASSARD, C. A. BIZOLLON, \\ AND R. FRANCOIS
}

Hîpital E. Herriot and Hôpital Debrousse, Lyon, France

Extract

Five patients with Bartter's syndrome were investigated. Sodium restriction $(<10 \mathrm{mEq} /$ day for at least 5 days $)$ showed a renal sodium wastage in only two patients $(I$ and $I I)$ in spite of increased aldosterone secretion rate (from 151-427 to 680-842 $\mu \mathrm{g} / \mathrm{day}$ ). The effect of angiotensin II (A II) $80 \mathrm{ng} / \mathrm{kg} / \mathrm{min}$ for $30-180 \mathrm{~min}$, on plasma renin activity (PRA), plasma aldosterone, and urinary sodium excretion was compared with the effect of a previous infusion of $5 \%$ dextrose given at the same rate, $0.5 \mathrm{ml} / \mathrm{min}$ for $1 \mathrm{hr}$. A II infusion resulted in increased plasma aldosterone levels: from $236-330 \mathrm{pg} / \mathrm{ml}$ to $800-881 \mathrm{pg} / \mathrm{ml}$ in $30 \mathrm{~min}$. This increase was also observed in patient II (from 139 to $600 \mathrm{pg} / \mathrm{ml}$ ). PRA was decreased by $A$ II infusion (from 1,142-2,462 to $121-1,625 \mathrm{ng} / \mathrm{liter} / \mathrm{min}$ ). In patient $I V$, this decrease in PRA was also observed when he was on a salt-restricted diet (from 1,934 to $370 \mathrm{ng} / \mathrm{liter} / \mathrm{min}$ ); but the minimal PRA was still higher $(370 \mathrm{ng} / \mathrm{liter} / \mathrm{min})$ than with a normal diet $(121 \mathrm{ng} / \mathrm{liter} / \mathrm{min})$. In no case could normal PRA level be obtained. A II infusion induced an increase in urinary sodium excretion only in the two patients with renal sodium wastage (from $80-90$ to $265-230 \mu \mathrm{Eq} / \mathrm{min}$ in $30 \mathrm{~min}$ ). Urinary sodium excretion decreased in the other patients from $(37.5-213$ to $4.30-46 \mu \mathrm{Eq} / \mathrm{min})$ and fractional sodium excretion was reduced in patient $V$ (from $0.56 \%$ to $0.45 \%$ at $30 \mathrm{~min}$ and to $0.29 \%$ at $120 \mathrm{~min}$ ). No signifi- 
cant change with $A$ II infusion was observed in patient $I V$ when he was on a sodium-restricted diet (from 1 to $2.5 \mu \mathrm{Eq} / \mathrm{min}$ in 30 min). Urinary potassium excretion was similar to sodium excretion. No change was observed in plasma potassium and sodium.

\section{Speculation}

Hypersecretion of renin is not autonomous in Bartter's syndrome. It is not explained by an insensitive feedback effect of A II on renin secretion. Hypokalemia contributes to this high level of PRA. Salt craving, which is found in $\mathbf{5 0} \%$ of the cases (28), is increased by $A$ II. Nevertheless, the presence of renal sodium wastage cannot be explained only by the high A II levels which are constant in this syndrome. A deficient Na-K-ATPase activity is postulated in such cases.

The highest levels of PRA and A II are observed in Bartter's syndrome $(1,2)$. However, the mechanism of excessive secretion and their role in pathophysiology is not yet clearly understood. A II has been shown to stimulate aldosterone secretion and to suppress renin secretion in Bartter's syndrome $(10,13)$. Modlinger et al. (20) have observed an increase in renal sodium excretion under A II infusion in one patient.

Two types of Bartter's syndrome can be described in childhood according to the presence or the absence of renal sodium wastage (28). In order to elucidate the regulation of the renin-aldosterone axis and the role of A II on urinary sodium excretion in these two types of Bartter's syndrome, five patients were investigated: two had renal sodium wastage and three were without renal sodium loss. The effects of sodium restriction and of A II infusion on PRA, aldosterone secretion, and renal excretion of sodium and potassium were studied.

\section{MATERIALS AND METHODS}

\section{CASE REPORTS}

Patient I. BP, a boy born March 14, 1954, was admitted to Hopital E. Herriot at the age of $5 \frac{1 / 2}{2}$ years because of polyuria, polydipsia, and growth retardation. He had a normal birth (birth weight $4,500 \mathrm{~g}$ ) after a full term pregnancy. Physical examination was normal with normal weight $(18,800 \mathrm{~kg})$ but short stature $(1 \mathrm{~m}$; $2 \mathrm{SD})$. Blood pressure was $100 / 70 \mathrm{~mm} \mathrm{Hg}$.

On admission, serum potassium was $2.3 \mathrm{mEq} /$ liter. Subsequent determinations revealed persistent hypokalemia $(1.9-3.5 \mathrm{mEq} /$ liter) with metabolic alkalosis. Serum sodium was $136 \mathrm{mEq} /$ liter and urea nitrogen $30 \mathrm{mg} / 100 \mathrm{ml}$. Urine volume varied from 1,000 to $2,200 \mathrm{ml}$. Urinary excretion of potassium was found to be between 17 and $75 \mathrm{mEq} / 24 \mathrm{hr}$. Proteinuria was detected $(2 \mathrm{~g} / 24 \mathrm{hr})$ with a tubular electrophoretic pattern. Urine cultures were negative. Urine was negative for glucose and amino acid chromatography was normal. Creatinine clearance was $130 \mathrm{ml} / \mathrm{min} / 1.73 \mathrm{~m}^{2}$. Maximum urinary concentration after $12 \mathrm{hr}$ of water restriction was $602 \mathrm{mOsm} / \mathrm{kg} \mathrm{H} \mathrm{H}_{2} \mathrm{O}$. Impaired urinary acidification was observed. Bone marrow and slit lamp examination were normal. High basal PRA $(1,142 \mathrm{ng} /$ liter/min; normal for age $54 \pm 10)$ and aldosterone secretion rate $(427 \mu \mathrm{g} / 24 \mathrm{hr})$ were found. Renal biopsy showed enlargement of the juxtaglomerular apparatus with typical hypokalemic features. Exchangeable sodium was low: $38.24 \mathrm{mEq} /$ $\mathrm{kg}$ body weight (normal for age $45-55 \mathrm{mEq} / \mathrm{kg}$ ); exchangeable potassium was also low: $24.5 \mathrm{mEq} / \mathrm{kg}$ of lean mass (normal for age $40 \mathrm{mEq} / \mathrm{kg}$ ).

The patient was treated with chloride sodium $(6-20 \mathrm{~g} / 24 \mathrm{hr})$ and chloride potassium $(7-20 \mathrm{~g} / 24 \mathrm{hr})$. Spironolactones $(300 \mathrm{mg} / 24 \mathrm{~h})$ were given from $81 \% 12$ to 18 years of age with a transient increase in serum potassium.

At the age of 10 years Cushing's syndrome was discovered; it was successfully treated with aminogluthetimide (750 mg-2.25 $\mathrm{g} / 24 \mathrm{hr}$ ) for 8 years and the cortisol secretion rate dropped from 40 to $21 \mathrm{mg} / \mathrm{m}^{2} 24 \mathrm{hr}$ (normal values $11 \pm 5 \mathrm{mg} / \mathrm{m}^{2} / 24 \mathrm{hr}$ ). Two episodes of rickets with hypophosphoremia $(2.3-2.9 \mathrm{mg} / 100 \mathrm{ml})$ were treated with $30 \mathrm{mg}$ vitamin $D_{2}$. The patient was $191 / 2$ years old when A II infusion was performed; spironolactone and aminogluthetimide were discontinued after $1 \frac{1 / 2}{2}$ years. A detailed description of this case has been reported (24).

Patient II. $A T$ is a boy born November 25,1959 . He was admitted for the first time to Hôpital Debrousse for hypotrophy, polyuria, and polydipsia at the age of $13 \frac{1}{2}$ years.

Physical examination showed only low weight $(27,400 \mathrm{~kg} ;-2$ $\mathrm{SD})$ and short stature $(134 \mathrm{~cm} ;-3 \mathrm{SD})$ Blood pressure was $100 / 70$ $\mathrm{mm} \mathrm{Hg}$.

On admission, serum potassium was $2.8 \mathrm{mEq} /$ liter and subsequent hypokalemia was recorded $(1.8-3.6 \mathrm{mEq} / \mathrm{liter})$. It was associated with hyperkaluria $(25-68 \mathrm{mEq} / 24 \mathrm{hr})$. Serum sodium was $135 \mathrm{mEq} /$ liter, chloride $98 \mathrm{mEq} /$ liter, carbon dioxide 24 $\mathrm{mEq} /$ liter. Urine volume was between 3.5 and 5 liters/day. Urine was negative for protein and glucose and amino acids chromatography was normal. Creatinine clearence was $81 \mathrm{ml} / \mathrm{min} / 1.73 \mathrm{~m}^{2}$. Maximum urinary osmolality after $12 \mathrm{hr}$ of water restriction was $333 \mathrm{mOsm} / \mathrm{kg} \mathrm{H} \mathrm{H}_{2} \mathrm{O}$. Urinary acidification was normal. Further investigations showed high PRA (186 ng/liter/min; normal for age $35 \pm 12)$ and aldosterone secretion rate $(151 \mu \mathrm{g} / 24 \mathrm{hr})$. Juxtaglomerular hyperplasia was observed on renal biopsy. Bone marrow and slit lamp examination were normal. Bone x-rays and intravenous pyelogram were normal. Treatment was carried out with potassium chloride (10 g/day) and spironolactones (200 $\mathrm{mg}$ /day) without any change in kalemia.

Patient III.JS was born May 13, 1969. She weighed 1,700 g at the $32 \mathrm{nd}$ week of an uneventful pregnancy. She was admitted to Hôpital Debrousse for the first time at the age of $35 / 12$ years because of persistent vomiting. Physical examination showed only an emaciated girl with low weight $(10,500 \mathrm{~kg} ;-3 \mathrm{SD})$ and growth retardation $(85 \mathrm{~cm} ;-3 \mathrm{SD})$. Blood pressure was $85 / 60 \mathrm{~mm} \mathrm{Hg}$.

On admission, transient hypoglycemia $(23 \mathrm{mg} / 100 \mathrm{ml})$ was observed, but all of the endocrinologic and metabolic investigations were normal. Hypokalemia (1.8-3.5 mEq/liter) was associated with hyperkaluria $(15-32 \mathrm{mg} / 24 \mathrm{hr})$. Serum sodium was 140 $\mathrm{mEq} /$ liter, chloride $92 \mathrm{mEq} /$ liter, carbon dioxide $22 \mathrm{mEq} /$ liter, and urea nitrogen $33 \mathrm{mg} / 100 \mathrm{ml}$. Urine volume varied from 200 to $500 \mathrm{ml} /$ day. Proteinuria $(0.80 \mathrm{~g} / 24 \mathrm{hr})$ showed a tubular electrophoretic pattern. Urines cultures were negative. No glycosuria was detected and amino acid chromatography was normal. Creatinine clearance was $118 \mathrm{ml} / \mathrm{min} / 1.73 \mathrm{~m}^{2}$. Maximum urinary concentration after $12 \mathrm{hr}$ of water restriction was $1,500 \mathrm{mOsm} / \mathrm{kg}$ $\mathrm{H}_{2} \mathrm{O}$. No impaired urinary acidification was detected. Bone $\mathrm{x}$-rays and intravenous pyelogram were normal. Bone marrow and slit lamp examination were normal. Further investigations showed high PRA (483 ng/liter/min; normal for age $111 \pm 39$ ); aldosterone secretion rate was at the lower limit of normal range $(58.5$ $\mu \mathrm{g} / 24 \mathrm{hr}$ ). Renal biopsy revealed typical juxtaglomerular hyperplasia. Treatment was carried out with potassium gluconate ( 7 $\mathrm{g} /$ day) and triamterene (100 $\mathrm{mg} /$ day). However, no change in kalemia was observed.

Patient IV. HN was born May 19, 1960. Diabetes mellitus was discovered at the age of $10 \frac{1}{2}$ years and was satisfactorily treated with long acting insulin with doses between 26 and $42 \mathrm{U} /$ day. Persistent hypokalemia $(2.2-2.8 \mathrm{mEq} /$ liter $)$ was discovered at the age of $132 / 12$ years by systematic investigations. His physical examination was normal (weight $35 \mathrm{~kg}$, height $137 \mathrm{~cm}$ ). Blood pressure was $90 / 50 \mathrm{~mm} \mathrm{Hg}$. Serum sodium was $142 \mathrm{mEq} /$ liter, chloride $97 \mathrm{mEq} /$ liter, carbon dioxide $28 \mathrm{mEq} /$ liter, urea nitrogen $38 \mathrm{mg} / 100 \mathrm{ml}$, and glucose $76-118 \mathrm{mg} / 100 \mathrm{ml}$. Urinary protein $(0.7 \mathrm{~g} / 24 \mathrm{hr})$ showed typical tubular electrophoretic pattern. No amino acid abnormalities were detected. Urinary cultures were negative. Urinary glucose was found to be between 8.52 and 42 $\mathrm{g} /$ day. Hyperkaluria $(35-58 \mathrm{mEq} / 24 \mathrm{hr})$ was found in spite of hypokalemia. Bone $x$-rays and intravenous pyelogram were normal. Further investigations showed high PRA (268 ng/liter/min; normal for age $35 \pm 7)$ and high plasma aldosterone $(288 \mathrm{pg} / \mathrm{ml})$. 
Table 1. Effect of salt-restricted diet $(\mathrm{Na}<10 \mathrm{mEq} /$ day) on urinary sodium, plasma renin activity $(P R A)$, aldosterone secretion rate $(A S R)$, and plasma aldosterone

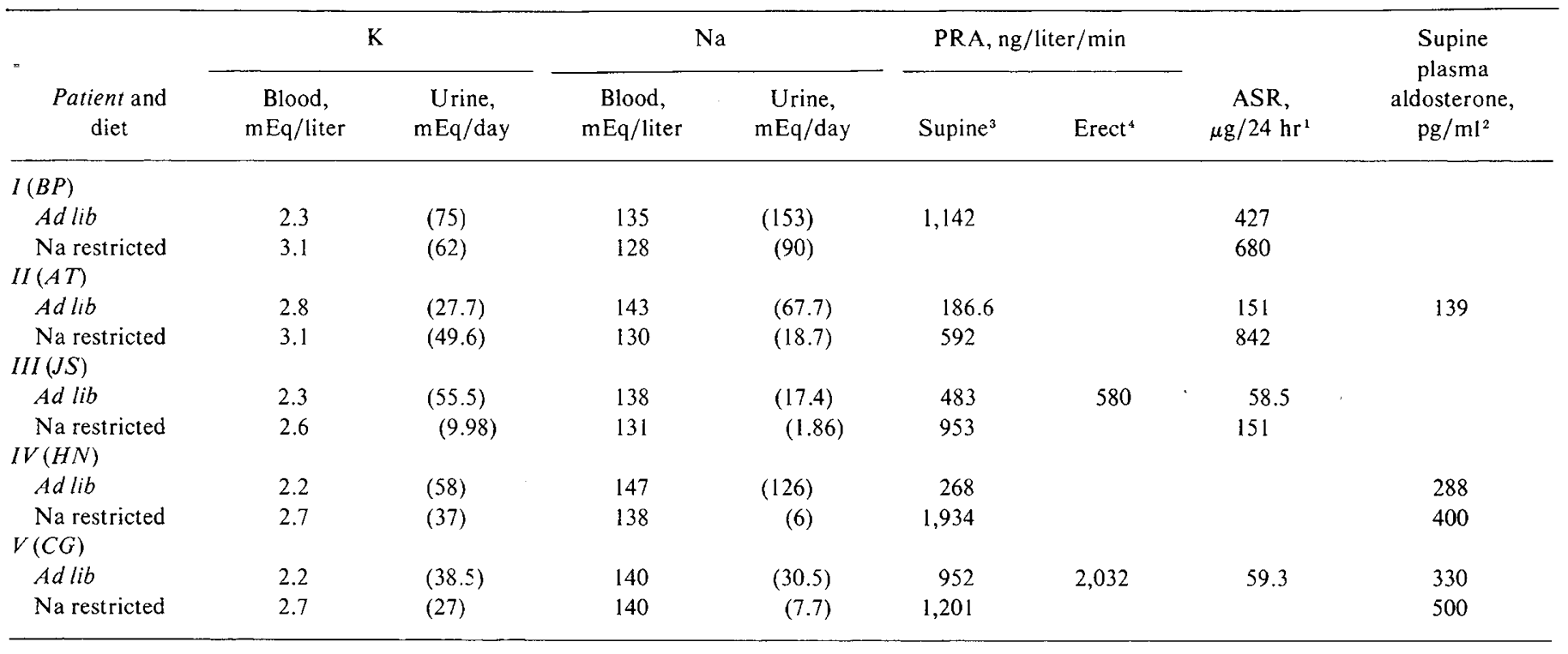

'Normal value $=60-120 \mu \mathrm{g} / 24 \mathrm{hr}$.

${ }^{2}$ Normal value (in adults) $=15-40 \mathrm{pg} / \mathrm{ml}$.

${ }^{3}$ Normal value (in adults) $=25 \pm 3 \mathrm{ng} / \mathrm{liter} / \mathrm{min}$.

${ }^{4}$ Normal value (in adults) $=30 \pm 3 \mathrm{ng} /$ liter $/ \mathrm{min}$.

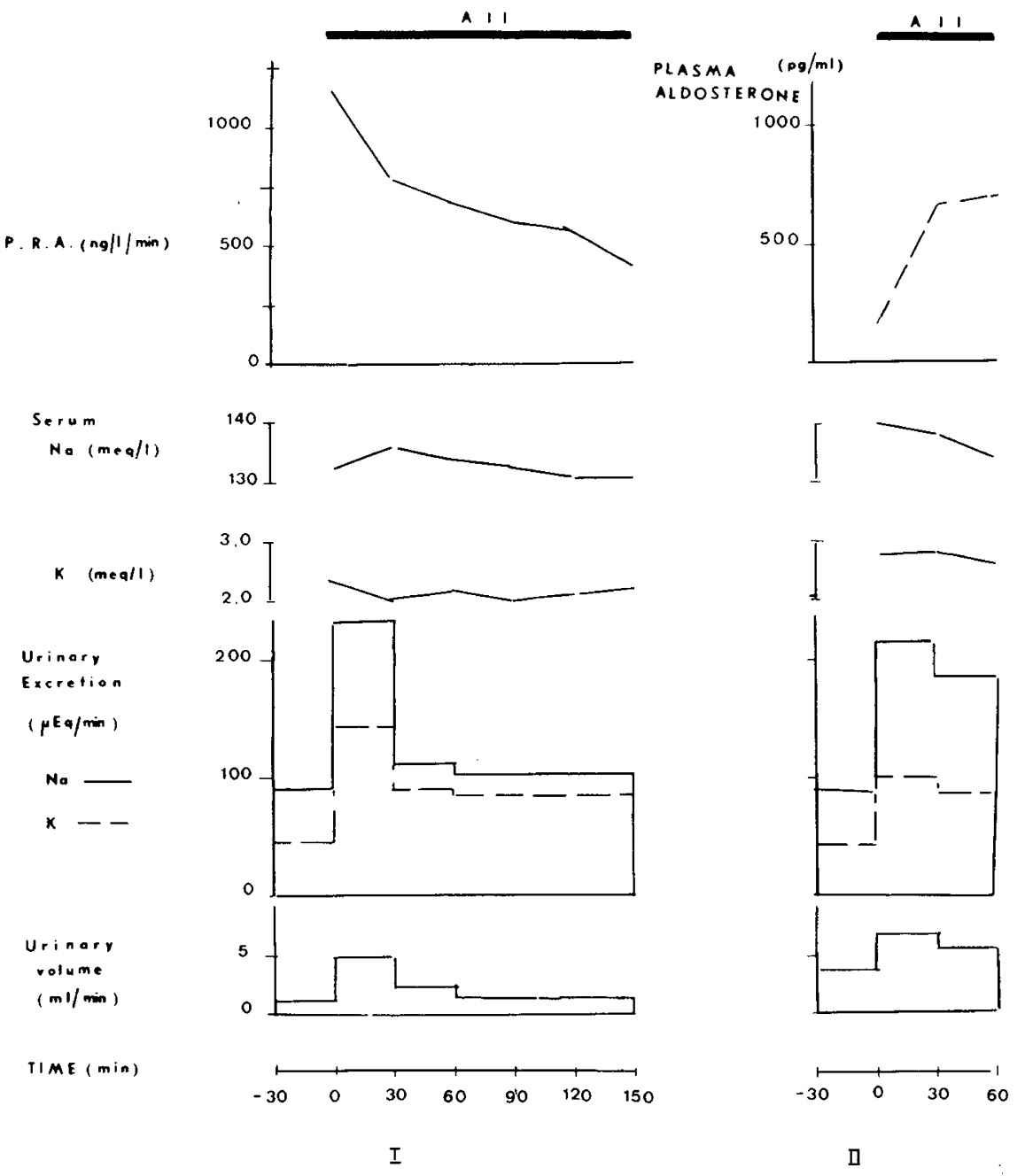

Fig. 1. Effect of angiotensin II $(A I I)$ infusion on plasma renin activity $(P . R . A$.) plasma aldosterone, serum and urinary sodium and potassium in the patients with renal salt loss. 

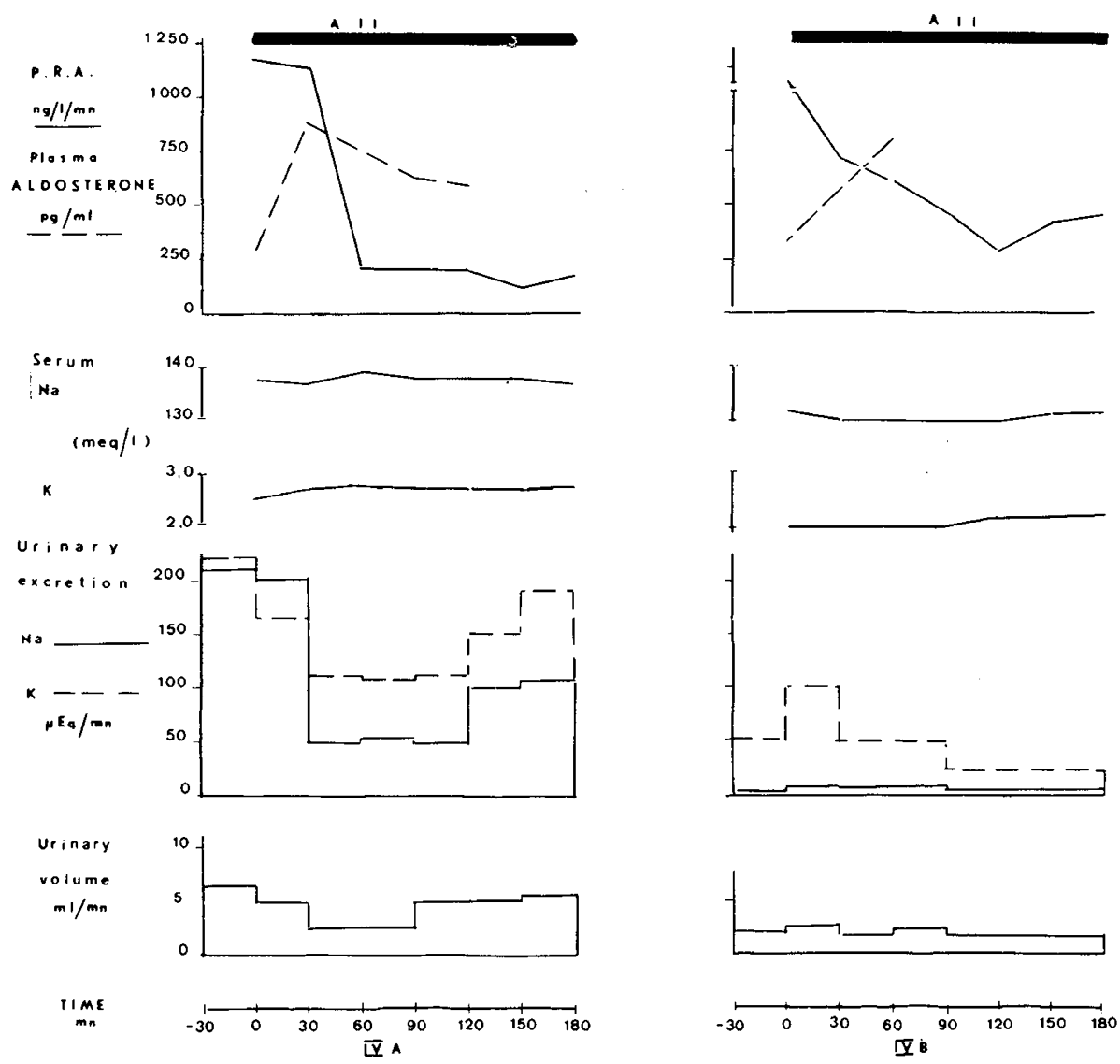

Fig. 2. Effect of angiotensin II $(A I I)$ infusion on plasma renin activity $(P . R . A$.) plasma aldosterone, serum and urinary sodium and potassium in one patient without renal salt loss. IVA: patient $I V$ on a normal diet; $I V B$ : patient $I V$ on a salt-restricted diet $(\mathrm{Na}<10 \mathrm{mEq} / 24 \mathrm{hr})$.

A II

serung

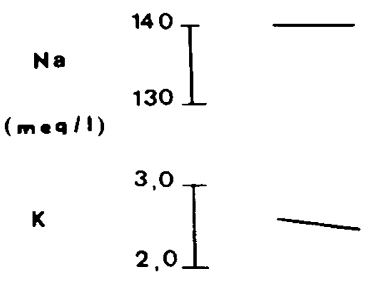

Urinary

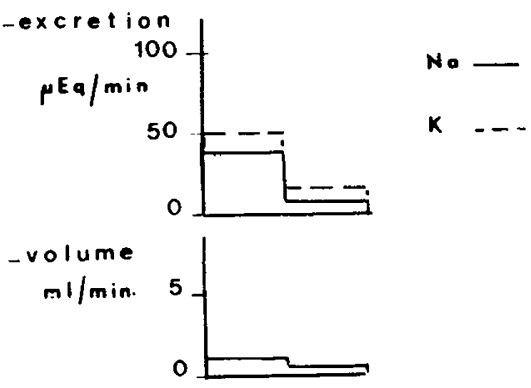

TIME $\min$

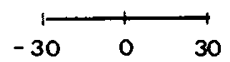

Fig. 3. Effect of angiotensin II $(A I I)$ infusion on plasma and urinary sodium in patient III.
Creatinine clearence was $132 \mathrm{ml} / \mathrm{min} / 1.73 \mathrm{~m}^{2}$. Bone marrow and slit lamp examination were normal. In addition to insulin, treatment included potassium gluconate $(12 \mathrm{~g} /$ day $)$, triamterene (300 mg/day), and $\mathrm{NaCl}$ (10 g/day). No change in serum potassium and PRA could be observed.

Patient V.CG was born October 22, 1968. She was first admitted to Hôpital E. Herriot at the age of 6 years because of vomiting and growth retardation. Physical examination showed only short stature $(97 \mathrm{~cm} ;-3.5 \mathrm{SD})$ with low weight $(12 \mathrm{~kg} ;-3$ $\mathrm{SD}$ ). Blood pressure was $90 / 50 \mathrm{~mm} \mathrm{Hg}$. Serum potassium was 1.6 $\mathrm{mEq} /$ liter on admission; subsequent hypokalemia $(1.8-3.1 \mathrm{mEq} /$ liter) and hyperkaluria (36-45 mEq/liter) were detected. Serum sodium was $140 \mathrm{mEq} /$ liter, chloride $82 \mathrm{mEq} /$ liter, carbon dioxide $20.5 \mathrm{mEq} /$ liter, urea nitrogen, $27 \mathrm{mg} / 100 \mathrm{ml}$. Urine volume was $1,000 \mathrm{ml} / 24 \mathrm{hr}$. Urine cultures were negative and no urine glucose was detected; amino acid chromatography was normal.

Proteinuria $(0.10 \mathrm{~g} /$ day $)$ showed mixed glomerular and tubular pattern at immunoelectrophoresis. Creatinine clearence was 118 $\mathrm{ml} / \mathrm{min} / 1.73 \mathrm{~m}^{2}$. Maximum urinary osmolality after $12 \mathrm{hr}$ of water restriction was $768 \mathrm{mOsm} / \mathrm{kg} \mathrm{H}_{2} \mathrm{O}$. Further investigations showed high PRA (952 ng/liter/min; normal for age $54 \pm 10$ ) and high plasma aldosterone level $(330 \mathrm{pg} / \mathrm{ml})$. Juxtaglomerular hyperplasia was observed on renal biopsy. Bone marrow and slit lamp examination were normal. Exchangeable sodium was $45^{\circ}$ $\mathrm{mEq} / \mathrm{kg}$ body weight (normal for age $45-55 \mathrm{mEq} / \mathrm{kg}$ body $\mathrm{wt}$ ). Treatment was carried out with amiloride $(5 \mathrm{mg} /$ day). Serum potassium and PRA remained at abnormal levels.

\section{MEASUREMENTS AND PROCEDURES}

These were all carried out before any treatment was started or when the treatments were discontinued for at least 2 weeks. Informed consent of the parents was obtained in all cases. Aldosterone secretion rate was measured by gas chromatography 
with a modified method of Flood et al. (11). Venous samples of PRA and plasma aldosterone assays were taken in the morning (8-9 AM), the patient resting recumbent in bed for at least a few hours. Blood was directly collected in tubes containing EDTA and kept on ice. After centrifugation at $+4^{\circ}$, plasma was immediately separated and frozen at $-20^{\circ}$. PRA (27) and plasma aldosterone (3) were determined by radioimmunoassay. Normal results of PRA for age have been reported previously (25). Sodium restriction was performed for at least 5 days with a controlled diet providing less than $10 \mathrm{mEq}$ of sodium every day. Dietary intake of sodium was estimated by standardized tables (9). Serum and urinary electrolytes were determined by flame photometry. A II infusion was based on the procedure of Kaplan and Silah (17). The effect of a suprapressive rate of A II was tested on PRA and plasma aldosterone. At the same time, the effect of A II in 5\% dextrose on serum and urinary sodium and potassium was compared with a previous infusion of only $5 \%$ dextrose. First, as in the procedure of Modlinger et al. (20), A II infusion was performed for $30 \mathrm{~min}$ (patients $I I$ and $I I I$ ). It was then performed for $180 \mathrm{~min}$ in the other patients.

Therefore, $5 \%$ dextrose in water was first infused at the rate of $0.5 \mathrm{ml} / \mathrm{min}$ for $60 \mathrm{~min}$ in all the patients but one (patient II). Then, hypertensin (Ciba) in 5\% dextrose was infused at the same rate and at concentration of $80 \mathrm{ng} / \mathrm{kg} / \mathrm{min}$ for $30-180$ minutes. These infusions were all performed in early morning on recumbent patients. Blood and urinary samples were collected every $15 \mathrm{~min}$ in patient $I I$ and every $30 \mathrm{~min}$ in the other patients.

\section{RESULTS}

\section{SODIUM RESTRICTION}

Table 1 shows the effect of sodium restriction in the five patients. PRA and aldosterone secretion increased in all the patients. Renal sodium wastage in spite of increased aldosterone secretion was detected only in patients $I$ and $I I$.

\section{ANGIOTENSIN II INFUSION (FIGS. I-4)}

No change of blood pressure was observed in any case. A II induced a sharp decrease in PRA in the patients who could be studied. When patient IV was on a sodium-restricted diet (Fig. 3), a similar decrease in PRA was observed but the minimal PRA was was still higher. In no case could a normal PRA be obtained. A II infusion always resulted in a marked increase in plasma aldosterone levels.

An immediate and dramatic increase in urinary sodium excretion was detected in the patients with renal sodium wastage (Fig. 1). This increase was particularly important during the first $30 \mathrm{~min}$ in patient $I$. In patient $I I$, it occurred in spite of increased plasma aldosterone. The other patients showed no similar increase in urinary sodium excretion. Moreover, a reduction of fractional sodium excretion was observed in patient $V$ (Fig. 4). No change of sodium excretion was obtained in patient $I V$ when he was on a sodium-restricted diet (Fig. 2, $I V B$ ). Urinary potassium excretion
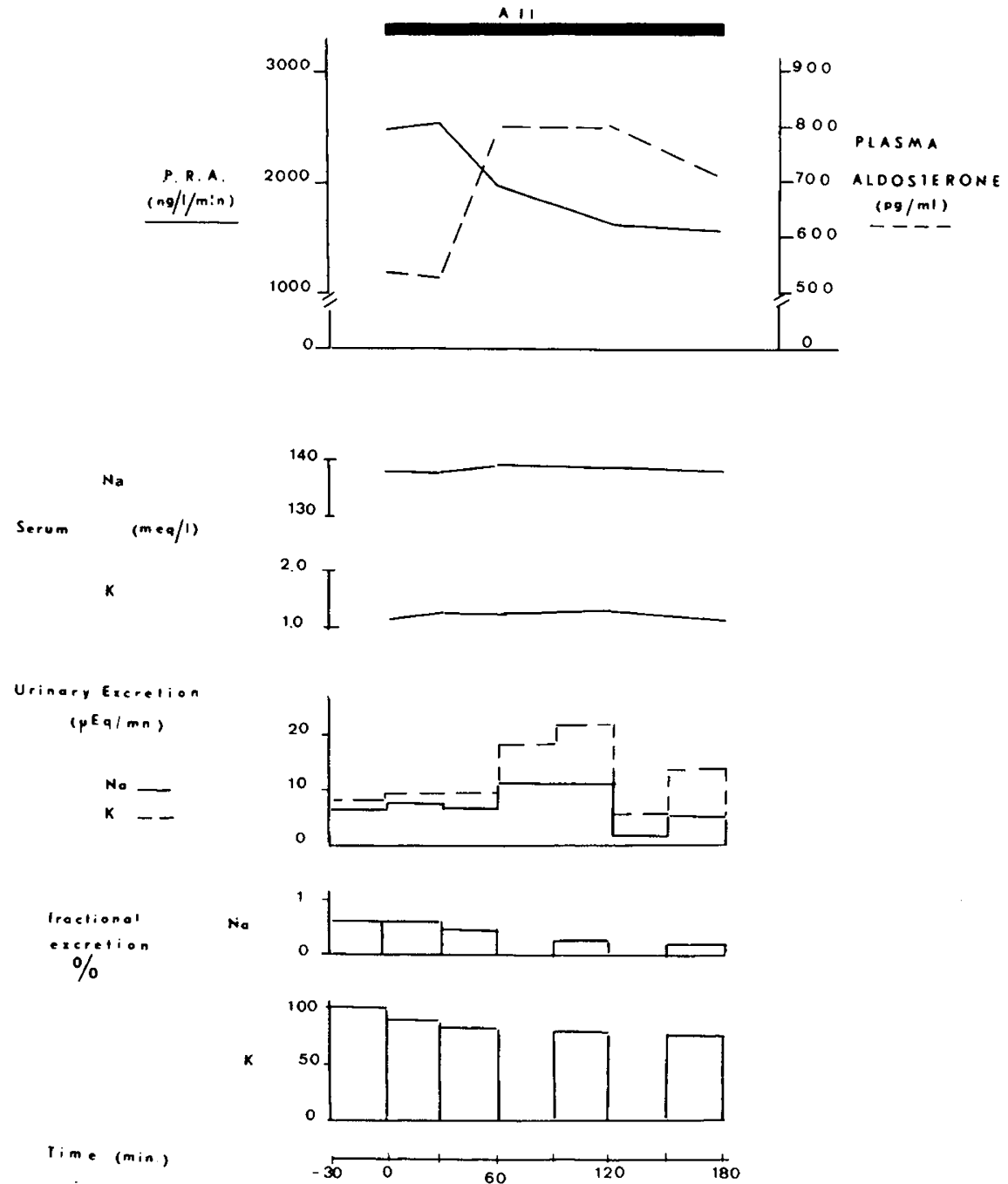

Fig. 4. Effect of angiotensin II $(A I I)$ infusion on plasma renin activity $(P . R . A$.) plasma aldosterone, blood and urinary sodium and potassium and on fractional excretion of sodium and potassium in patient $V$. 


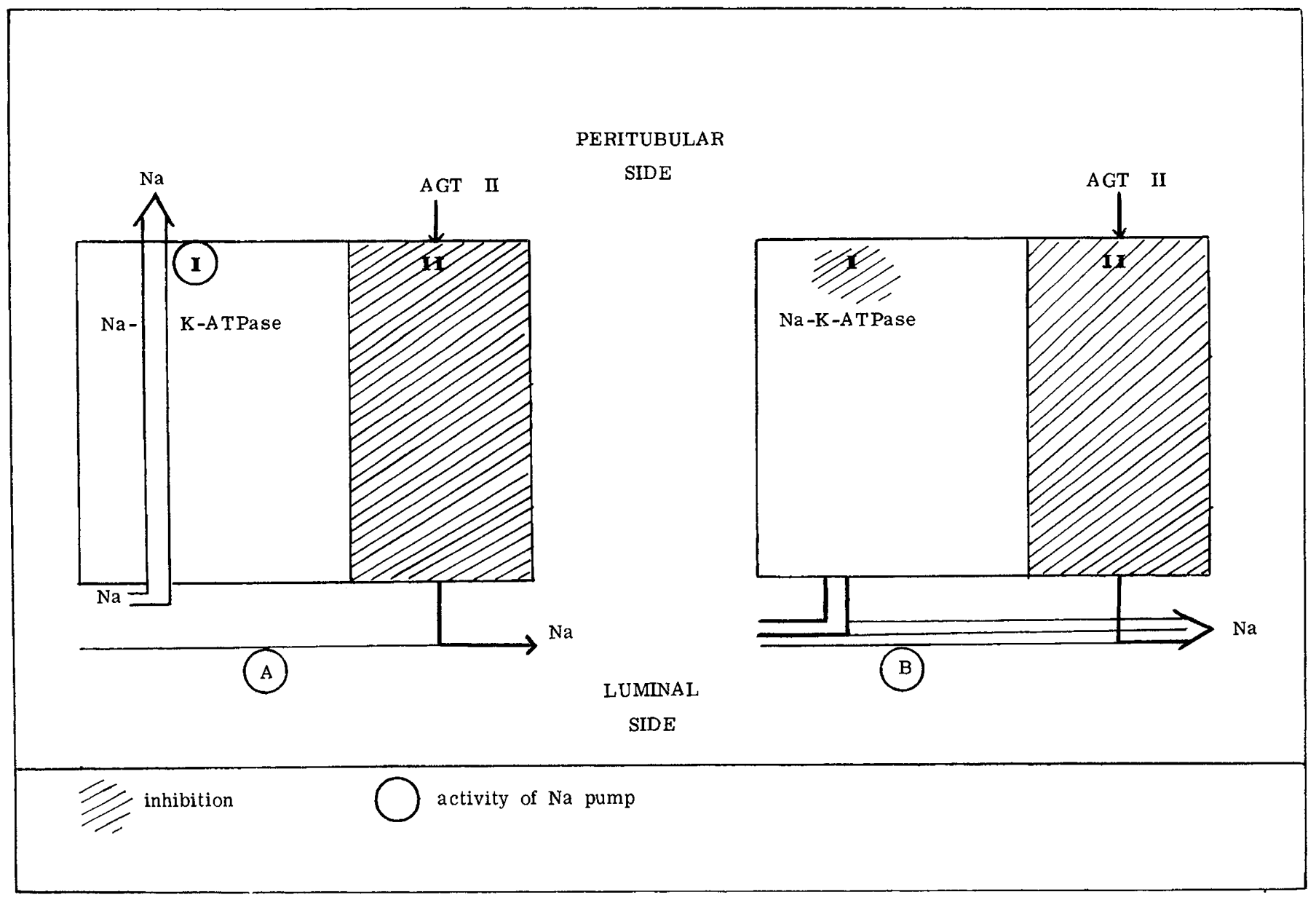

Fig. 5. Effect of angiotensin II $(A G T I I)$ on sodium reabsorption in the tubular cell. Angiotensin II decreases sodium pump II activity (and/or chloride-dependent reabsorption). $A$ : normal Na-K-ATPase activity; $B$ : decreased Na-K-ATPase activity.

was similar to the sodium excretion all patients. A dissociation was observed only when patient IV was on a sodium-restricted diet. The increase in urinary potassium occurred without any significant change in urinary sodium; at the same time, an increase in plasma aldosterone was observed.

Blood sodium and potassium remained unchanged during A II infusion.

\section{DISCUSSION}

The pathogenesis of renin hypersecretion in Bartter's syndrome is not known. The primary vascular insensitivity to A II proposed by Bartter $(1,2)$ is not yet accepted $(7,14,29)$. Then Brackett et al. (5) suggested the existence of an autonomous secretion of renin. However, sodium restriction results in normal increase in PRA and aldosterone secretion. On the other hand, a sharp decrease of PRA and plasma aldosterone under sodium infusion has already been described in patient $I(20)$. Therefore, there is a normal regulation of the renin-aldosterone axis by sodium restriction or infusion. It is known that A II has a suppressive effect on renin secretion (4). When A II was infused into our patients, this feedback effect was found. This result agrees with previous similar investigations $(10,13)$, but our results show that this feedback is found in patients with renal sodium wastage as well as in patients without sodium wastage. This decrease of PRA with A II infusion was observed even when patient $I V$ was on a salt-restricted diet. Therefore, this study demonstrates that the secretion of renin is not autonomous in both types of Bartter's syndrome.

Despite the normal regulation of the renin-aldosterone axis, a normal PRA could not be obtained under A II infusion. The persistent high PRA value could not be explained by a disturbance of sodium balance in patients $I V$ and $V$ since exchangeable sodium was normal in patient $V$, since sodium restriction did not result in renal sodium wastage, and because A II infusion induced no renal sodium wastage. The only persistent abnormality which could be observed in our patients was hypokalemia, which is known to induce high PRA levels $(6,26)$. Therefore, we strongly support the view of Godard et al. (13) that potassium per se could play a role in the pathogenesis of renin hypersecretion independent of any change in sodium balance.

Infusions of high concentrations of A II are known to induce a natriuresis. Modlinger et al. (20) observed increased urinary sodium excretion when A II was infused for $30 \mathrm{~min}$ in one case of Bartter's syndrome with renal sodium loss. The result was confirmed only in our patients with sodium wastage. In this condition, increased urinary sodium occurred during the first $30 \mathrm{~min}$. This effect was not observed in patients without sodium wastage; a marked reduction of fractional sodium excretion was observed in patient $V$.

Renal sodium loss was not explained by a defect of aldosterone secretion, since plasma aldosterone increased under A II infusion, in spite of hypokalemia. The increased urinary sodium excretion observed in spite of high plasma aldosterone in patient $I I$ could be possibly explained by the latent effect of aldosterone. Nevertheless, it is in keeping with sodium escape to aldosterone (24), which was observed when these patients were on a sodium-restricted diet. Therefore, renal sodium wastage in Bartter's syndrome cannot be explained by a hormonal imbalance and an intrarenal factor must be postulated.

The natriuretic effect of A II stems from an inhibition of sodium reabsorption in the ascending limb of the loop of Henle (16). According to the report of Munday et al. (21), A II inhibits the 
glycoside-insensitive sodium pump (pump II) but not the enzyme Na-K-ATPase (19). Furthermore, chloride participates in sodium reabsorption (23) and A II can inhibit this chloride-dependent sodium reabsorption (22). In Bartter's syndrome, there is also a defect of sodium reabsorption in the ascending limb of the loop of Henle (8). A deficient activity of Na-K-ATPase was recently described (15), but the defect of sodium transport was not recognized in all patients (12). Thus, the natriuretic effect of A II in Bartter's syndrome may depend on Na-K-ATPase activity and could be explained as following (Fig. 5): when pump II is inhibited by A II, an increased compensatory activity of Na-K-ATPase would result, especially under aldosterone stimulation (18), and no renal sodium wastage would be observed. On the contrary, if the activity of Na-K-ATPase is low, pump I could not compensate the inhibition of pump II by A II and renal wastage would occur. This possibility is supported by the dissociation between sodium and potassium urinary excretion which is observed only when patient $I V$ is on a sodium-restricted diet (Fig. 2). In this case, the increased urinary potassium excretion could be explained by the reactional aldosterone effect. However, our hypothesis needs further study, especially in keeping with the role of chloride in active transport of sodium $(22,23)$ and the effect of prostaglandins.

These results show that: (1) A II stimulates aldosterone secretion in these patients in spite of hypokalemia; (2) the feedback effect of A II on PRA exists even in patients with renal sodium wastage or when a patient is on a salt-restricted diet; (3) no normalization of PRA levels is observed and it is in keeping with the persistent hypokalemia; (4) the natriuretic effect of A II is found only in patients who show an escape to aldosterone during salt-restricted diet.

\section{SUMMARY}

Renin secretion is not autonomous in Bartter's syndrome. PRA levels were reduced by A II infusions but did not return to normal. This could be explained by the persistent hypokalemia. The natriuretic effect of A II was only observed in the salt-craving patients. Therefore, the presence of renal sodium wastage depends on an intrarenal factor.

\section{REFERENCES AND NOTES}

1. Bartter, F. C.: So-called Bartter's syndrome. N. Engl. J. Med., 281:1483 (1969)

2. Bartter, F. C., Pronove, P., Gill, J. R., and McCardle, R. C.: Hyperplasia of the juxtaglomerular complex with hyperaldosteronism and hypokalemic alkalosis. Amer. J. Med., 33: 811 (1962).

3. Bizollon, C. A Riviere, J.F Franchimont, P Faure, A and Claustrat B Solid phase radio immunoassay of plasma aldosterone. Steroids, 23: 809 (1974)

4. Blair-West, J. R., Coghlan, J. P., Denton, D. A., Funder, J. W., Scoggins, B. A., and White, R. D.: Inhibition of renin secretion by systemic and intrarenal angiotensin infusion. Amer. J. Physiol., 220: 1309 (1971)

5. Brackett, N. C., Koppel, N., Randall, R. E., and Nixon, W. P.: Hyperplasia of the juxtaglomerular complex with secondary hyperaldosteronism without hypertension (Barter's syndrome). Amer. J. Med., 44: 803 (1968).

6. Brunner, H. R., Baer, L., Sealey, J. R., Ledingham, J. G., and Laragh, G. H.: The influence of potassium administration and of potassium deprivation on plasma renin activity in normal and hypertensive patients. J. Clin. Invest., 49: $2128(1970)$.

7. Cannon, P. J., Leeming, J. M., Sommers, S. C., Winters, R. W., and Laragh, G. $H$.: Juxtaglomerular cell hyperplasia and secondary hyperaldosteronism (Bartter's syndrome): A reevaluation of the pathophysiology. Medicine, 47: 107 (1968).

8. Chaimovitz, C., Levi, J., Better, O.S., Oslander, L., and Benderli, A.: Studies on the site of renal salt loss in a patient with Bartter's syndrome. Pediat. Res., 7: 89 (1973).

9. Diem, K. (Ed.): Chemical composition of foods. In: Scientific Tables Geigy, p. 516 (Karger, Basel, 1963)

10. Fisher, C. E., Olambiwann, O., Frasier, S. E., and Horton R.: Renin-aldosterone dynamic in Bartter's syndrome [Abstract]. Clin. Res., 21: 282 (1973).

11. Flood, J. C., Gherondache, S. S., Pincus, G. S., Tait, J. F., Tait, S. A. S., and Willoughby, S. The metabolism and secretion of aldosterone in elderly subjects. J. Clin. Invest., 46: 960 (1967).

12. Gardner, J. D., Simopoulos, A. P Lapey, A and Shibolet, S: Altered membrane sodium transport in Bartter's syndrome. J. Clin. Invest., 51: 1565 (1972).

13. Godard, C., Vallotton, M. B., Broyer, M., and Royer, P.: A study of the inhibition of the renin-angiotensin system in potassium wasting syndrome, including Bartter's syndrome. Helv. Paediat. Acta, 27:495 (1972).

14. Goodman, A. D., Vagnucci, A. D., Vagnucci, A. H., and Hartroft, P. M.: Pathogenesis of Bartter's syndrome. N. Engl. J. Med., 281: 1435 (1969).

15. Haljamae, H., Enger, E., and Sigstrom, L.: Cellular potassium transport and ATPase activity in Bartter's syndrome. Scand. J. Clin. Lab. Invest., 35: 53 (1975).

16. Healy, J. K., and Elliot, A. J.: The effect of a natriuretic dose of angiotensin on rabbit kidney composition. Clin. Sci., 38: 727 (1970).

17. Kaplan, N. M., and Silah, J. G.: The effect of angiotensin on the blood pressure in human with hypertensive disease. J. Clin. Invest., 43: 659 (1964).

18. Knox, W. H., and Sen A. K.: Mechanism of action of aldosterone with particular reference to $(\mathrm{Na}+\mathrm{K})$ ATPase. Ann. N. Y. Acad. Sci., 242: 471 (1974).

19. Marc-Aurele, $J$, and Bergeron, $N$.: Lack of evidence for an inhibitory effect of angiotensin on $\mathrm{Na}+\mathrm{K}+$ adenosine-triphosphatase. Rev. Can. Biol., 27: 107 (1966).

20. Modlinger, R. S., Nicolis, G. L., Krakoff, L. R., and Gabrilove, J. L.: Some observations on the pathogenesis of Bartter's syndrome. N. Engl. J. Med., 289: 1022 (1973).

21. Munday, K. A., Parson, B. J., and Poat, J. A.: The effect of angiotensin on cation transport by rat kidney slices. J. Physiol., 215:269 (1971).

22. Poat, J. A., Parsons, B. J., and Munday, K. A.: Effects of angiotensin on transporting epithelial [Abstract]. J. Endocrinol., 68: 490 (2P) 1976.

23. Rochas, A. S., and Kokko, J. P.: Sodium chloride and water transport in the medullary thick ascending limb of Henle: Evidence for active chloride transport. J. Clin. Invest., 52: 612 (1973).

24. Sann, L., Moreau, P., Longin, B., Sassard, J., and Francois, R.: Un syndrome de Bartter associant un hypercortisolisme, un diabète phosphoré et magnésien et une tubulopathie d'origine familiale. Arch. Franc. Pediat., 32: 349 (1975).

25. Sassard J., Sann, L., Vincent, M., Francois, R., and Cier, J. F.: Plasma renin activity in normal subjects from infancy to puberty. J. Clin. Endocrinol. Metab., 40: 524 (1975)

26. Vander, A. J.: Direct effects of potassium on renin secretion and renal function. Amer. J. Physiol., 219: 853 (1970).

27. Vincent, M., Sassard, J., and Cier J. A.: Méthode rapide de détermination radioimmunologique de l'activité rénine du plasma. Rev. Europ. Clin. Biol., 17: 1001 (1972)

28. Wald, M. R., Perrin, E. V., and Bolande, R. P.: Bartter's syndrome in early infancy. Pediatrics, 47: 254 (1971).

29. White, M. G.: Bartter's syndrome. Arch. Int. Med., 4l: 129 (1972)

30. We thank Professors Jeune, Larbre, and Monnet for allowing us to study their patients. We are indebted to Miss I. Ghali for reviewing the manuscript. We thank Miss Jeanne de Sainte-Hermine for secretarial help.

31. Requests for reprints should be addressed to: L. Sann, M.D., Service de Néonatalogie, Hôpital Debrousse, 29, rue Soeur Bouvier, 69002 Lyon (France). 32. Accepted for publication June 4, 1976. 